\title{
PLURALISM OF VALUES: ITS SCOPE AND LIMITATIONS
}

\author{
Abderrahmane Taha* \\ (abridged translation from Arabic by Karim D. Crow)
}

\begin{abstract}
Value Pluralism is an ethico-political philosophical doctrine upholding the principle of the clash of values which decrees that values are heterogeneous and incommensurable among themselves. The appearance of this doctrine was surrounded by specific conditions: 1 . The recent condition based on the principle of conflict between reason and religion, serving as the cause for a manifestly unrestrained rationality. 2. Liberalism based on the principle of conflict between politics and ethics, serving as the cause for a pervasive political hegemony. 3 . The idea of the 'clash of civilisations' based on the principle of conformity between culture and ethics, and serving as the cause of a far-reaching cultural extremism. The upholders of Value Pluralism pursued conflicting methods in dealing with this valuational clash: 1. The method of 'determination' (Max Weber and Isaiah Berlin), 2. The method of 'demonstration' (J. Habermas and K.-O. Apel), 3. The method of 'separation' (John Rawls), and 4. The method of 'connecting' (Michael Walzer). All this calls for seeking a new value pluralism upholding the principle of 'coinciding values' feasible only by eliminating the causes of clash comprising three defects: rational unrestraint, political hegemony, and cultural extremism. The author, in turn, repels the defect of unrestrained rationality by disseminating the value of faith into reason, dispels the defect of hegemony by disseminating the value of the Good into politics, and dislodges the defect of extremism by disseminating the value of human 'innate nature' into culture.
\end{abstract}

On the translation: Certain key notions with the definite-article in Arabic are here capitalised in English to convey their technical import; important phrases emphasised in italics follow the Author's practice; Arabic terms are sometimes given in parentheses to clarify meaning; pronoun referents are often replaced by their antecedent nouns; and several sentences from the notes are inserted into the text, to improve reader comprehension and flow of meaning. Notes are added by

* Dr Abderrahmane Taha is the President of the Wisdom Circle for Thinkers and Researchers in Rabat, Morocco. Dr Karim D. Crow is Principal Research Fellow at IAIS. The original Arabic title of Dr Taha's article, as submitted to this journal, is "Ta'addudiyyat al-qiyam: Mā madāhā wa mā ḥudūduhā?" 
the translator, also in square brackets [KC], explicating thinkers or ideas mentioned by the Author [AT] to aid comprehension by those unfamiliar with philosophical ethics. The Author's original extensive bibliography has been omitted for reasons of space and his final paragraph appears now as the Abstract.

\section{Introduction}

We introduce our discourse on the topic of 'Pluralism of Values' by defining the meaning of its two subsidiary concepts - namely 'Value' and 'Pluralism'. It is well known that the word 'value' is a noun of aspect which in conventional usage indicates the worth of something or its valuation, while in technical usage it denotes various meanings exceeding or falling short of this conventional usage according to the fields it occurs in. Thus, in the philosophical domain we are concerned with here, 'value' conveys: the ethical import [al-ma' nā al-khuluqī] worthy for the human to wholly attend to by striving to attain its requirements through his actions. Based on this philosophical definition of the term 'value' we are permitted to employ two other terms in its place. One of these is specific to philosophers - the term 'ideal' or 'the highest ideal' [al-mithāl al-a' lā]. Among those ideals philosophers concerned themselves with in the past are 'The Good' and 'Truth' and 'Beauty', while among those they occupy themselves with today are 'Freedom' and 'Equality' and 'Justice'. The second term is specific to legal theoreticians of $u s \underline{u} l$ al-fiqh: the term 'intentobjective' [maqsid]. ${ }^{1}$ Among the higher objectives which the $u s \underline{u} l \bar{l}$-scholars derived from shari 'ah texts are three: 'Religion' and 'Reason'² and 'the Self' - and by 'the Self' [al-nafs] they intend 'Life' [al-hayāt].

It is also well known that the noun 'pluralism' is an applied verbal-noun employed to indicate the characteristic feature derived from the term 'plurality' in the sense that 'pluralism' connotes the specific quality of something being manifold.diverse [muta addid]. But what is intended here by employing this verbal-noun in conjunction with the word 'values' - as in our title - is not to distinguish values by this pluralist quality; rather what is intended is nothing else than: the orientation upholding the plurality of values, or one could say, the school of thought advocating the multiplicity of values; opposed to it is the school of thought advocating their unity.

1. [AT here refers to three of the five fundamental "Higher-Objectives of the Shari 'ah" in Islamic legal theory, the maqūssid al-sharī ah, as developed by scholars from al-Juwaynī and al-Ghazālī onwards, and elaborated systematically by later authorities, above all by al-Shātibī; consult Ahmad Al-Raysuni, Imām al-Shātibī's Theory of the Higher Objective and Intents of Islamic Law, tr. N. Roberts (Kuala Lumpur: IIIT and Islamic Book Trust, 2006), 16f. Finding an explicit equivalence between ethico-philosophic ideals and legal maqāsid is intellectually valid, yet admittedly only implied in the thought of earlier Muslim authorities. AT expands on this equivalence in the final section "Evaluation of Value Pluralism" of this article by creatively applying maqāssid to the ethical domain. $\mathrm{KC}]$

2. [We render $a l$ - $a q l$ as 'reason', yet it may also denote 'intelligence' and 'intellect'. KC] 
The philosophers had employed both concepts 'pluralism' and 'unicity', or in the old terminology, 'the doctrine of multiplicity' and 'the doctrine of unity'. ${ }^{3}$ Let us now proceed to discuss the specific qualities of the 'Pluralism of Values', or one could say 'Value Pluralism' [al-ta'addudiyyah al-qiyamiyyah], as a definite doctrine. In order to preserve the absolute opposition between 'pluralism' and its antonym, we propose to employ the term 'unicity' [al-tawahhudiyyah, i.e. monism] to convey this antonym, so we say 'Value Unicity' in opposition to 'Value Pluralism'.

\section{Particular Qualities of 'Value Pluralism'}

It is possible to maintain that 'Value Pluralism' is an orientation of far-reaching influence in contemporary political and ethical philosophy, ${ }^{4}$ since this trend confirms the role of values in human life by placing them among the ideal factors [al-muqawwimāt al-mainawiyyah] through whose existence this life thrives and becomes wholesome and by whose absence life is vitiated and becomes malignant. It likewise confirms that these values whose presence makes life wholesome or absence makes life malignant are of multiple types and aspects. Among them are ethical values and non-ethical values, and within each portion of these two major divisions are a variety of types. Examples of ethical values whose benefit relates to the other are: love and friendship and trustworthiness; while examples of non-ethical values whose benefit relates to one's self are: kinship-descent and noble-achievement $[a l-h a s a b]$ and beauty. The source of this value related multiplicity is the multitude of modes which human life assumes and the multitude of stages through which this life fluctuates.

Nevertheless, the most important characteristic distinguishing this trend of Value Pluralism is its assertion that certain foundational values upon which the Good Life is based are contradictory or contesting - one may say clash with each other - in as much as removing this clash is not possible by means of restoring some of these values to some other, nor by means of giving preponderance to some of them over another. By way of example: the incompatibility of Life with Freedom

3. The philosophers first employed both terms in the domain of Existence [al-wujūd]. Thus, they understood 'pluralism' as advocating that Existents [al-mawjūāt $]$ in the world designate a multiplicity of individual essential-substances [jawāhir fardiyyah] subsisting independent of one another, as with Descartes when he upheld the existence of two essential-substances: 'the body substance' and 'the spirit substance'. This is opposed to the doctrine of 'unicity' tracing the totality of things back to a single essential substance, as with the Materialists [al-māddiyyūn, today termed 'Physicalists'] who trace every thing back to physical-matter, or the Idealists [al-mithāliyyūn] who trace back every thing to the spirit [immaterial-substance].

4. Among the Pluralist philosophers we find: John Stuart Mill, Max Weber, William James, Isaiah Berlin, A. Baier, R. Brandt, S. Hampshire, T. Nagel, D. Norton, M. Nussbaum, M. Oakeshott, J. Rawls, M. Stocker, P. Strawson, Charles Taylor, and B. Williams. 
when sacrificing one's Life becomes the price to attain Freedom; just as Life is incompatible with Justice when exposure to self-destruction becomes the means to repel injustice; likewise complete Freedom is incompatible with complete Equality. Hence, Value Pluralism grounds the Good Life upon the attainment of multiple clashing values.

This value clash [al-tașādum al-qīmī] does not derive from practical causes such as the deficiency of information or the crookedness of demonstrative proofs; that is to say, neither attaining an increase of data nor accomplishing correct proofs is of absolutely any utility in removing this clash. Likewise this clash does not derive from linkage of these values with the subjective personality of the human [dhāt al-insān] - as Value Subjectivism claims when it deems values to be merely a special responsiveness and stimulated reactions. ${ }^{5}$ Nor does this clash derive from the linkage of values with a culture in and of itself - as Value Relativism claims when it makes every value depend upon a particular cultural context. ${ }^{6}$ That is the case because we are capable of comprehending the values of other peoples and their conceptions of the Good Life, without this comprehension of ours meaning we concur with them regarding such values; rather we raise objections to these values foreign to us and we reject them simultaneous with our comprehending them. ${ }^{7}$ On the contrary, this clash derives from the fact that the relation between values possesses two fundamental characteristics, namely: 'incommensurability' and 'disparity' [al-taghāyur wa al-tabāyun].

Incommensurability. ${ }^{8}$ What is intended by al-taghayur (as an equivalent for the English term 'incommensurability') is that neither of the two clashing values are receptive one to the other whether by analogy or by comparison, that being the case for the following reasons:

5. [al-dhätiyyah al-qiyamiyyah: Value Subjectivism or 'ethical subjectivism', the trend that relativises moral value to the individual subject by holding that the truth of moral statements depends upon people's values, attitudes, feelings, or beliefs - as with Cultural Relativism. KC]

6. [al-nisbiyyah al-qiyamiyyah: Value Relativism or 'cognitive relativism', the trend viewing ethical statements as not reflecting objective or universal truths, but instead making claims relevant to social, cultural, historical or personal circumstances - as with Logical Positivism. KC]

7. See C.J. McNight, "Pluralism, Realism and Truth", in: D. Archard (ed.), Philosophy and Pluralism (Cambridge: Cambridge University Press, 1996), 89.

8. [AT refers to the thesis by leading contemporary thinkers upholding moral relativism who assert there is no objective independent foundation for morality, claiming that morality is a social creation designed to resolve internal and interpersonal conflicts and is based on human interests and desires. Key to their argument is the notion of 'evaluative incommensurability': that we have no justification for our own most basic premises and forms of reasoning, so there is no way to show that others' views are inferior to ours. In other words, they point to fundamental differences in ethical beliefs and claim they are best explained by a relativist theory that denies a single true morality. See e.g., David Wong, "Three Kinds of Incommensurability”, in: Michael Krausz (ed.), Relativism: Interpretation and Confrontation (Notre Dame, IN: University of Notre Dame Press, 1989). KC] 
(a) either because there is not found any higher value - such as Happiness - from which these two values may branch out or in accordance with which their proper order proceeds; or

(b) because no intermediary or median exists - such as Pleasure - by which it is possible to evaluate or to assess these two values; or

(c) because no general principle exists which may be applied or no established rule which may be followed to exit this clash. ${ }^{9}$

The example of two incommensurable values are: Cognition and Compassion [alma'rifah wa 'l-rahmah], for it is not possible for us to compare or gauge one of these two by means of the other, nor for us to draw a parallel between these two on the basis of a standard norm shared by both; aside from the fact that the excess of one of these two values does not necessarily make it superior to the other nor be inferior to it in merit - even if it was conceivable that a third value exists surpassing one of them while not surpassing the other.

Disparity. What is intended by al-tabayun are two concepts. The first is logical disparity, which requires that it is not possible for the meaning of one of two clashing values to concur in our mind along with the meaning of the other value, such that when realisation of one is conceptualised then realisation of the second is prevented. The example of two logically disparate values is: Justice and Forgiveness. The second is practical disparity occurring between two logically disparate values, yet between the two exists a non-essential [ $\operatorname{arad} \bar{\imath}$, accidental or contingent] disparity resulting from practical causes related to specific circumstances or to the conditions of this world. The example of practical disparity is: 'a pleasant Married Life' and 'a Life wholly occupied with Knowledge', for there is no logical disparity between the two, however they oppose one another in the experience of some seekers of knowledge.

By this it becomes evident that these two qualities of 'incommensurability' and 'disparity' are distinguishable from one another. Thus it is not correct that every incommensurability is a disparity, since two values may be incommensurable between themselves without preventing the two coexisting together in the life of the individual - for it suffices that he widen his conception of the Good Life in such a manner that he makes it encompass these two values together at once. Likewise it is not correct that every disparity is an incommensurability, since two values can be disparate simultaneous with the possibility of comparative association between the two. Rather the general rule is the occurrence of disparity in things associated comparatively and in things related by nature. Therefore Value Pluralism bases the Good Life upon attaining a plurality of incommensurable and disparate values.

9. J. Kekes, The Morality of Pluralism (Princeton: Princeton University Press, 1996), 21-2, 56. 


\section{Conditions for 'Value Pluralism'}

After having defined the general characteristics of Value Pluralism considered as a distinct philosophical doctrine, we need to explain the objective circumstances connected to this doctrine and thereby the theoretical consequences resulting from this connection. We enumerate three of these circumstances:

\section{A recent circumstance: Being the 'Rationality of the World' 10}

Max Weber ${ }^{11}$ holds that owing to the action of rationality the human being is enabled to emerge from an enchanted world - namely, a world ruled by many gods whose intentions are concealed from humans yet which intervene in their life and destiny - into an understandable world ['ālam bașīr] devoid of enchantment, since the human being becomes capable of knowing it and subjugating it to his purposes; that is to say, a world devoid of every hidden transcendent meaning. ${ }^{12}$ However, with the steady increase of this human rationality and vanishing trace of the monotheism [al-tawhi $\bar{l}]$ brought by the Christian religion, these old gods, so to speak, began to emerge from their graves to control our life anew and resume their unending struggles, aiming by that for humans to substitute for the plurality of gods a plurality of values. In this respect one may speak of 'the polytheism of values' and 'the war of the gods'. ${ }^{13}$

From this it necessarily follows - concerning the priority of reason - that instead of leading to consolidating its authority, on the contrary this plurality of values led to rational unrestraint [al-tasayyub al- $a q l \bar{l}]$; and that concerning the triumph of rationality, instead of being associated with the flourishing of reason, on the contrary

10. ['aqlanatu ' $l$-'alam: the 'intelligibility' of the world or universe. KC]

11. [Maximilian C.E. Weber (1864-1920), the influential German political economist, sociologist and eclectic writer who founded several academic disciplines including modern sociology, public administration and organisational theory, and who also wrote on the ancient religions of Judaism, India and China. His The Protestant Ethic and the Spirit of Capitalism began his work in sociology of religion and rationalisation, reflecting his anti-positivist hermeneutic approach. The idea that fundamental values can conflict with each other is prominent in Weber's thought, captured in his notion of 'polytheism'. KC]

12. ['älamin khälin min kulli maqșidiyyah muta' äliyah khafiyyah. AT here refers to the transformation in world-view inaugurated by the Enlightenment and reinforced by Continental Rationalism, which divested itself of the 'irrational' ('superstitious' or 'magical') mindset prevailing in Europe's Middle Ages, shaking free from the authority of the Catholic Church to embrace secularity, science and reason. See Max Weber, Essais sur la théorie de la science, tr. J. Freund (Paris: Éditions Plon, 1965). KC]

13. In French: "le polythéisme des valeurs" and "la guerre des dieux"; see S. Mesure and A. Renaut, La guerre des dieux (Paris: Grasset, 1996). [AT evokes Europe's pre-Christian polytheism, wherein the pantheons of gods were viewed as indifferent or hostile to human wellbeing; exalting 'reason' above transcendent values is thus likened to the return of ancient pagan gods, echoing a theme first developed by Max Weber. KC] 
this plurality of values accompanied the dissolution of reason. Such unrestraint or dissolution of reason is represented in the appearance of multiple values clashing one against another. This separation (between values) in itself does not concern us here to the same extent as the cause behind it - namely that the intensification of rationality brought about the contradiction between the reason of humans and the religion of monotheism, thereby contributing to the fall into a new polytheism: the polytheism of values.

In this manner it is apparent that the 'rationality of the world' joined with plurality of values was founded on the basis of the contradiction between reason and religion, and this contradiction led to unrestrained rationality.

\section{An ideological circumstance: Being the 'Authority of Liberalism'}

It is known that 'Liberalism' is generally the political thought-current claiming a wide scope for individuals' pursuit of their freedoms without some of them interfering with the actions of others, and for realising their conceptions of the Good Life without the state interfering in it except preserving these freedoms. For this reason, Liberal theorists have recourse to the distinction between what they call "essential values" connected with individuals' conceptions of the Good Life specific to them, and what they call "enforced values" being public [al- 'ammah] values regulating the attainment of these essential values. Then they make the role of the state being to restrict these enforced common values. This means that Liberalism distinguishes between the political aspect promoted by the state as representing for the most part the principles of justice, and between the ethical aspect undervaluing the individual promoted by the state as representing the values of the Good. Rather the state goes further by placing the political aspect prior to the ethical.

Among Liberals we find those who endeavour to distinguish between Pluralism and Liberalism, invoking as proof that in the event of a clash Pluralism does not make one specific value preponderate over others, whereas in such a clash Liberalism privileges Liberal values including Freedom, Equality and Justice above what opposes them. ${ }^{14}$ Rather it goes to an extreme in adhering to these values to the degree of imposing hegemony [al-tasallut] over peoples in the name of these values. The proper view is that in Value Pluralism there is a privileging (of values), just as in Liberalism there is a privileging. Thus if Pluralism does not privilege specific values over others in any respect, as Liberalism does, nevertheless it privileges values with regard to specific circumstances in addition to its distinguishing between first and secondary principles, just as Liberalism distinguishes liberal values from others. ${ }^{15}$ In this manner, no wonder that Liberalism itself constitutes the political

14. See Kekes, Morality of Pluralism, 199-203; and also Charles Larmore, The Morals of Modernity (Cambridge: Cambridge University Press, 1996), 167.

15. Kekes, Morality of Pluralism, 18 and 211-17. 
thought-current that embraced Value Pluralism forcefully cooperating with it in discarding any grounding of the principles of political assembly upon the existence of an unseen intent·objective for the world [maqșid ghaybi $l i$ ' $l$-'älam].

By this, it is evident that 'Liberalism', which is combined with Value Pluralism, is grounded on the principle of conflict between politics and ethics, and this conflict leads to imposing political hegemony.

\section{A strategic circumstance: Being the 'Clash of Civilisations'}

It is known that the concept of 'clash of civilisations' Samuel Huntington ${ }^{16}$ put into circulation is a twofold concept, both descriptive and prescriptive at the same time. For Huntington did not content himself with describing the eight civilisational collectivities the world embraces historically and in actuality, but also marked out the policies these blocs must follow when dealing with each other. In its turn this mutual transaction is twofold: coexisting and conflicting at once, since this author contents himself with examining external differences and causes of contention between Western civilisation and the other civilisations, and with treating the possibilities of their entering into wars with one another. Moreover he expounds two opposing policies for confrontation or truce between them: either the policy of preserving Western hegemony, or the policy of upholding cultural pluralism. He distinguishes the concept of 'clash' from comparable notions such as 'contention' and 'struggle'given that with 'contention' the political character predominates, and with 'struggle' the economic character prevails - because 'clash' is distinguished by reliance on the cultural element in preference to the other two political and economic elements. Nothing is more conducive of a clash today than the entrenched conviction of the West regarding the all-embracing validity of its culture and civilisation. This leads it to a far-reaching extremism [tatarruf] in privileging its values, institutions and practices - alleging that its culture is the most enlightened and rational and latest mode of thought, and calling by all its means to enlist and encourage the peoples of the world to adopt it - despite the contradiction (Western civilisation displays) with certain values, institutions and practices of these peoples. ${ }^{17}$ In actuality such far-reaching extremism derives from the false congruity between culture, which is itself an offspring varying with the diversity of nations, and between the ethical

16. [Samuel P. Huntington (1927-2008) the American political scientist and member of Harvard University's Department of Government from 1950 until his death, whose controversial policy theory on the Clash of Civilizations in a post-Cold War world order brought him international fame. Between 1977 and 1978 he was White House Coordinator of Security Planning for the National Security Council in the administration of Jimmy Carter. Huntington's early work The Soldier and the State: The Theory and Politics of Civil-Military Relations (1957) is deemed the most influential book on American civil-military relations. KC]

17. See S.P. Huntington, Le choc des civilizations (Paris: Éditions Odile Jacob, 1997), 343-4. 
notions culture embraces which may at times not differ in a particular component with the diversity of these nations. ${ }^{18}$

At this point, it is clear that the clash of civilisations, being joined with Value Pluralism, was erected on the principle of congruity between culture and ethics, and this congruity leads to cultural extremism.

\section{Methods of Dealing with the Clash Between Values}

On the basis of these three principles - namely: "the principle of contradiction between reason and religion" which arose from the recent circumstance for the plurality of values, and "the principle of contradiction between the political and ethical" which arose from the 'ideological' circumstance for this pluralism, and "the principle of conformity between the cultural and the ethical" which arose from the 'strategic' circumstance for this pluralism - we will now examine the methods which 'Liberals' employ in dealing with the phenomenon of the clash of values. These are four methods: determination, rational-demonstration, separation, and connecting [al-taqrīr, al-tadlīl, al-tafrīq, al-tajmī'].

\section{The Method of Determination}

The famous German social scholar Max Weber, ${ }^{19}$ and likewise the English philosopher of Latvian origin Isaiah Berlin,${ }^{20}$ held that the clash of values is an attribute that can never be disconnected from human life, yet the two differed in their position towards it and in defining its causes.

It appears that Weber considered this value clash a negative attribute, since he saw the new rationality in its confrontation with the internal and external events of life as leading to the appearance of clashing views and disparate values resembling 'polytheism' in their multiplicity. It is not possible to actualise these views and values save by a struggle occurring between them resembling the 'war of the gods', for every one of these views and values is venerated by their possessor and there is no

18. Ibid, 353 .

19. See Max Weber, "Le métier et la vocation de savant", in: Le savant et le politique, tr. J. Freund (Paris: Plon, 1959).

20. See Isaiah Berlin, Eloge de la liberté, tr. J. Carnaud and J. Lahana (Paris: Calmann-Lévy, 1988); idem, Le bois tordu de l'humanité, tr. M. Thymbres (Paris: Éditions Albin Michel, 1992). [Sir Isaiah Berlin (1909-1997) was a political theorist and historian of ideas at Oxford University deemed among the leading twentieth-century liberal thinkers. His writings on the Counter-Enlightenment contributed to his advocacy of the ethical theory of value pluralism (or 'objective pluralism'). In Berlin's account of value pluralism, moral values may be equally or incommensurably valid and yet incompatible, and may therefore conflict with one another in a way that admits of no resolution without reference to particular contexts of decision. In his Two Concepts of Liberty (1958) and Liberty (Oxford: Oxford University Press, 2002), his notion of Negative Liberty is central to the claim for toleration due to incommensurability. $\mathrm{KC}$ ] 
possibility to demonstrate that one of the clashing values is superior or preferable to another. ${ }^{21}$

As for Berlin he considered this value clash a positive attribute, since he held that the values which different societies aspire to during various time periods, or that different groups within one society or individuals within one group aspire to, are multiple and dissimilar among themselves - there being no possibility of accommodation between these values in any respect whatsoever even if they all be objective and fundamental notions. ${ }^{22}$ However, the world wherein plurality exists becomes richer and more beneficial than the world lacking plurality, since it opens the door to diverse possibilities for traversing life and expands the sphere of freedom and modes of behaviour.

When Weber and Berlin deem that dispelling this clash over values is not possible - due to the impossibility of demonstrating these values according to the former, and the impossibility of accommodation between them according to the latter - they both claimed that human decision [al-irādah] alone is what determines which of two clashing values becomes realised, in the sense that we unavoidably choose one of the two in an arbitrary unjustifiable manner, our selection accompanied by our feeling regret for what eluded us in not choosing the other value. Thus, the method which Weber and Berlin adopted in dealing with valuational clash is not one of rational vindication, rather it is volitional determination.

\section{The Method of Demonstration}

It is known that rational-demonstration is the opposite of determination. Jürgen Habermas $^{23}$ and Karl-Otto Apel, ${ }^{24}$ the two German philosophers of the second

21. See S. Mendus, “Tragedy, Moral Conflict and Liberalism”, in: David Archard (ed.), Philosophy and Pluralism (Cambridge: Cambridge University Press, 1996), 191.

22. See Berlin, Le bois tordu de l'humanité, 88 .

23. See for example: J. Habermas, Morale et communication, tr. and intro. C. Bouchindhomme (Paris: Éditions du Cerf, 1986). [Jürgen Habermas (1929-) is an influential German social philosopher, critical theorist and self-described 'methodological atheist' best known for his concept of the 'public sphere'. His Theory of Communicative Action (1981) focused on the public role of religion in secular contexts and the significance of discourse ethics for rationality. Habermas offers a comprehensive theory of societal evolution and modernisation focusing on the difference between communicative rationality and strategic or instrumental rationality. He emphasises the potential for transforming the world and arriving at a more humane, just, and egalitarian society by means of institutionalising the potential for rationality inherent in the communicative competence unique to humans. $\mathrm{KC}]$

24. See for example: K.-O. Apel, L'éthique á l'âge de la science (Lille: Presses Universitaires de Lille, 1987). [Karl-Otto Apel (1922-) is a German philosopher noted for his work in ethics and philosophy of language, now Professor Emeritus at the University of Frankfurt am Main, combining the critical perspectives of Pragmatism and the Frankfurt School. Apel co-developed the theory of communicative action and discourse ethics with his collaborator Jürgen Habermas, and as a leading opponent of so-called 'critical rationalism' made a comprehensive refutation of the philosophy of Karl R. Popper. KC] 
generation of the critical Frankfurt School, in treating the clash of values sought to follow a method based on demonstration. They both had in mind a special type of demonstration: it ought not to be the activity of self-absorbed inward looking reflective reason, but rather the activity of an interconnective reason wide open to the community. Nor should it rely on existential rationalism [aqlāniyyah kiyāniyyah] claiming conformity with reality in its essential nature, but rather rely on procedural rationalism ['aqlāniyyah ijrā'iyyah] content with defining the bases on which the object of demonstration is proven true. Defining the conditions of validity that the value judgment should properly fulfil, is necessarily based on the requirement of this interconnective procedural reason - these conditions Habermas summed up in two principles:

First, the principle of universality whose requirement is that the value judgment is not valid except if everything proceeding from its general application - with the purpose of fulfilling the interests of every one - is acceptable on the part of all concerned individuals, meaning the value judgment has no validity without consensus.

Second, the principle of debate whose requirement is that the value judgment is not valid except when all concerned individuals in their role as contenders agree upon its validity, meaning the value judgment has no validity without debate.

From this it is clear that debate is a dialogue characterised by the disputants establishing rational evidences for the validity of value judgments. In other words, debate is marked by what we may call 'collective validating demonstration' ${ }^{25}$ since it is open to reclaiming mutual understanding and consensus whenever contention occurs concerning this or that value judgment - to the point of calling for renewing this dialogue numerous times or even continuing it without end.

But Apel maintains that there remains in this validating demonstration something of determination inasmuch as it stops short of validating value judgments, not passing beyond to validate the principle of universality itself upon which these judgments are built; rather it determines the truth of this principle by decision. The situation is that removing the value clash may only be achieved by validation of this principle calling for the agreement of all rational people. This validation takes the form of an ultimate basis for Apel, since he shows how every dialogue whatsoever comprises various comprehensive pre-conditions for intercourse. These include, for example, the necessity that I interact with my dialogue-partner on the condition of his being equal to me in sound demonstration, and I assume he speaks truthfully with me just as I am truthful with him, and I cooperate with him in attaining the correct

25. Clearly the term al-tașhīh here does not mean 'rectifying' (al-tașwīb or al-taqwīm) as when we say 'correcting the mistake/tașhīh al-khața'; rather its meaning is 'establishing validity/iqämat al-sihhah' as when we say 'the proof by which judgment is valid'. 
outcome, just as we should only depict as valid the judgment reached by agreement that excludes no one. If that be the case, the contender dropping any one of these conditions must contradict himself, since it is not possible he dispute it except by making use of it. The principle of universality is itself one of these obligatory prevailing conditions, so the objector to it contradicts himself since his objection in reality is an affirmation of it; like when someone says, "Ask everybody to affirm the truth of the following proof: The proof-seeker does not require everyone to affirm the validity of continuously prevailing precepts for demonstrative proof, namely confirming that they lead to consensus;" ${ }^{26}$ or in brief, "Seek to drop consensus due to the non-validity of consensus." It follows from this basis that the interactive conditions upon which dialogue is grounded serves as a group of universal values encompassing all of humanity.

The outcome is that Habermas and Apel treat valuational clash as equivalent to implementing rational-demonstration at two dissimilar levels: a validating demonstration and a foundational demonstration. As for the validating demonstration which Habermas adopts, he removes norms of validation from the sphere of the clash in view of the fact that these norms are ethical intuitions grounded in ongoing daily experience. He also affirms that settling contests by means of proofs is better than settling them by means of violence, and that the clash does not occur except in values which themselves are below these living norms, and for whose validity we appeal to these selfsame norms. While for the foundational demonstration adopted by Apel, he does not exclude norms of validation from the clash as long as their application is not effected upon an ultimate basis, since without such demonstration the norms remain mere arbitrariness or determinations. This ultimate basis discloses itself in the self-contradiction of the person opposing them, for such norms shape the very requirements of his demonstration - meaning that on the contrary the sought-for foundation in the final analysis is 'reason' or 'rationality'. If that be the case then it is possible to bolt the door on clashing values, except that Habermas sees in this foundation only a renunciation of the interconnective consensual reason and a retreat to pure contemplative reason - for both he and Apel make whoever renounces interconnective reason as siding with their thinking about countering valuational clash. ${ }^{27}$

Thereby it becomes clear how the opposition between reason and religion erected by the 'rationality of the world' opened the path to such privileging of rationaldemonstration when dealing with the clash of values, since it offered both its advocates Habermas and Apel an opportunity to maintain one of the two opposites i.e., reason, and to avert the other i.e., religion - by upholding reason - because

26. K.O. Apel, "L'éthique de la discussion: sa portée, ses limites", in: A. Jacob (ed.), Encyclopédie Philosophique Universelle 1: 154-65.

27. See Mesure and Renaut, La guerre des dieux, 191. 
these two thinkers rely upon the basis of reason and abandon reliance on religion. This upholding of reason takes two forms: one is a relative form represented by accepting societal values uncritically as Habermas does; the second is an unrestricted form represented by substituting 'proof-of-reason' in place of 'faith-in-reason' as with Apel.

\section{The Method of Separation}

The American philosopher John Rawls ${ }^{28}$ holds that pluralism is a remarkable event in Liberal society due to the difficulties of judging things by reason, the obscurity of basic notions, difference in viewpoints, personal specificity of experiences, disparity in appraisals, and predicament of choices ${ }^{29}$ just as he holds that removing the value clash ensuing from these difficulties should be through separation. He strongly affirms the division in human life between the public sphere and private sphere, and he makes the public sphere distinguished by a group of values every individual in society should share in, whereas he makes the private sphere embrace values distinguishing every individual from the other and defining one's conception of the Good Life, so that values are multiple only in this second sphere alone. The shared values distinctive to the public sphere essentially revolve around 'Justice'.

In order for Rawls to demonstrate this separation between the public sphere embracing Justice and the private sphere embracing the conceptions of the Good Life, he resorts to imagining a primal condition wherein veils are hung between people and their knowledge of many of their conditions, beneficial interests, situations and roles so that these characteristics and viewpoints do not influence what they resolve and agree on. ${ }^{30}$ When they need to distribute limited resources among themselves, they are led by virtue of this isolation to fashion two principles regulating this distribution in the most equitable manner. One fulfils the right of each person to enjoy essential freedoms to the maximum extent in accord with the measure that others enjoy. The second requires that political and social differences be related to circumstances and situations granted to all under the auspices of equal opportunity, just as it requires realising the greatest benefit to disadvantaged groups in society.

28. [John Rawls (1921-2002) was a leading American moral and political thinker noted for advocacy of liberal political philosophy. In A Theory of Justice (1971) and its sequel Political Liberalism (1993) he expounded his key ideas of justice as fairness, the veil of ignorance, and the 'difference principle'. Rawls separated the public realm in which an absolute moral standard of liberal justice is universally applicable and supported, and the private realm in which the liberal idea of freedom of conscience and respect for value pluralism is preserved. $\mathrm{KC}]$

29. See John Rawls, Libéralisme politique, tr. C. Audard (Paris: Presses Universitaires de France, 1993), 85-6.

30. Clearly Rawls here circumscribes the formula 'theory of social contract' which Hobbes, Rousseau and Kant subscribed to before him. 
Based on this separation between the values associated with Justice and the values associated with the Good Life or good-things, Rawls is able to restrict plurality to the sphere of the Good and take it out of the sphere of Justice. Thus everyone has his private conception of the Good, but all people share in the principle of Justice, and their sharing in these procedural principles by its very nature places fetters on their private conceptions of the Good, thereby making the pluralism resulting from these conceptions, according to Rawls' wording, intelligible pluralism, and every conception of the Good departing from these principles is deemed to be an unintelligible conception.

Thereupon it is clear that the method of separation Rawls pursues conforms to the opposition Liberal thought raises between politics and ethics - knowing that he is reckoned among its chief theoreticians who strove to renew its structure. Thus Justice in as much as its domain is public is a political affair, while the Good in as much as its domain is private is an ethical affair. The opposition between political and ethical is susceptible to two ordering aspects: "the precedence of the political over the ethical" and "the precedence of the ethical over the political". Rawls adopts the first aspect thus making Justice precedent in rank over the Good as priority of condition over conditioned-object, since if not for Justice then there would be no Good. Likewise he gives Justice precedence in distinction in terms of priority of the pre-eminent over the less excellent, for Justice is the absolutely pre-eminent excellent quality.

\section{The Method of Connecting}

It is known that connecting is opposed to separation. Critiquing the above-mentioned position of Rawls, the American philosopher Michael Walzer ${ }^{31}$ holds that plurality befalls all values whatever they may be, hence it is not possible to exempt Justice from plurality as Rawls does. For Justice itself comprises a plurality of domains, since the principles of distribution on which Justice is based vary with the variety of resources [al-khayrāt, good-things] which are inseparable from their social context and their meanings relative to the members of this context; but one good may achieve distribution by multiple means within different contexts in accordance with the understanding of those affected by its nature. ${ }^{32}$ When this is the case the procedure of separating Justice and Good which Rawls follows is voided, and joining collective

31. [Michael Walzer (1935-) is an American political philosopher and noted public intellectual now professor emeritus at Princeton's Institute for Advanced Studies, who has written on just and unjust wars, nationalism, ethnicity, economic justice, social criticism, radicalism, tolerance, and political obligation. Walzer is seen as a leading advocate of 'Communitarian' ideas in political theory; is noted for revitalising just war theory; as well as for his argument that justice is a moral standard within particular nations and societies, not a universalised abstraction. KC]

32. See M. Walzer, Spheres of Justice (Oxford: Martin Robinson, 1983); tr. P. Engel, Sphéres de justice (Paris: Seuil, 1997). 
absolute values and specialised particular values is necessary. However this joining, as Walzer views it, is not the supervision of absolute values over particular values ${ }^{33}$ - or 'joining from above', nor is it grounding the particular value upon the absolute value - or 'joining from below'; rather it is the penetration of the part within the whole, or in his expression: the penetration of the nearest limit within the farthest limit, or enveloping of the thin within the thick. ${ }^{34}$

Elucidation of this: collective ethical values are not prior notions and perceptions for all people initially, whereupon they produce from its garb social and historical apparel specifically suited to their fellows and thus come to differ between themselves, or as if these notions were initially thin or near then finally became thick or remote. On the contrary these notions in reality began thick or remote, then were absorbed originally into the ethical speech of a particular people, and the thickness comes from none other than this specific absorption. But despite the force of this absorption, it is not unlikely that specific circumstances transpired such as social crises and political oppositions, so these notions become manifested in their integral subtlety through such circumstances, and people participate together in mutually cognising them whatever the specificality of their ethical speech was. [AT gives a concrete example of the operation of collective ethical values: if we witness a demonstration by people from an alien culture holding placards reading 'Justice!' and 'Rights!' - we wish to join with them by directly recognising their intent and the values they appeal to.]

In sum, ethical values possess two aspects: one is a thick aspect peculiar to each community alone due to its connection with the specific culture and history of that community; owing to this aspect ethical values become multiple. The second is a thin aspect participated in together by all the human individuals, and not made manifest to them except during momentous events or rare tribulations befalling this or that community, and owing to this aspect these ethical values form a unity [tatawahhadu]. Based on this, Walzer's method in treating value clash is coupling between the particular and the collective, in so far as values are shared in common among individual humans and are exclusively distinctive among social groups, while those shared in common do not control distinctively particular values nor establish them.

Thereby it is clear that the 'connecting' Walzer chose as a method of treating value clash encompasses 'separation', for the reason that the collective ethical side, while not detached in actuality from the particular ethical side, has no means of drawing up

33. See M. Walzer, Pluralisme et démocratie (Paris: Éditions Esprit, 1997), 83-110.

34. See M. Walzer, Thick and Thin, A Moral Argument at Home and Abroad (Notre Dame, IN: University of Notre Dame Press, 1994). [AT's wording here is more imaginally evocative than Walzer's prose and prompts conceptual resonances specific to Islamic thought: "[...] dukhül alhadd al-adnā fì ' 'l-hadd al-aqsā aw intiwā' al-lațîf fĭ 'l-kathīf'. Replacing 'thin and thick' by 'subtle and dense' might evoke this dimension. KC] 
a universal language for formulating and conveying it. The collective side implicitly admits of such detachment because participation of the other particular side in its ethical notions is incontestably confirmed through the distinctive particularity of its culture. Or we could say metaphorically that these two sides, the collective and the particular, are joined from the viewpoint of reality, separated from the subjective viewpoint. Given this, we are not surprised that the author of Clash of Civilizations when establishing the opposition between culture and ethics has recourse to none other than Walzer to confirm that there exist ethical constants and ideal universal inclinations in all cultures. These are what we ought to seek instead of upholding the specific characteristics of a culture, claiming they are universal characteristics by generalising from its particular reality. ${ }^{35}$

\section{Evaluation of Value Pluralism}

We have finished discussing the qualities by which Value Pluralism is distinguished and conditions associated with it, as well as methods of dealing with the clash issuing from it. It remains for us to subject this doctrine to the test of critical appraisal and examine whether difficulties present themselves restricting its significance. We have seen how this pluralist doctrine with its requisite conditions is built upon three principles, namely: 'the principle of contradiction between rational and religious' and 'the principle of contradiction between political and ethical' and 'the principle of conformity between cultural and ethical'. It is sufficient for realising our objective of evaluation to direct our critique toward these principal axioms.

\section{Uncontested Givens of the Critique}

Our starting point for this critique is three assertions we had furnished proof for in another place; ${ }^{36}$ but here we shall treat them as Givens:

(a) Human Actions are all ethical acts. ${ }^{37}$ The elucidation of this is that human actions fall into two major divisions: one is actions directly actualising ethical objectives as when the human speaks truthfully or fulfils his promise, this being the habitual usage for designating acts by the name of 'Ethics'. The second division is actions serving as means for realising ethical objectives, and this

35. See Huntington, Le choc des civilizations, 353. [Such a claim is characterised by AT as "cultural extremism'. $\mathrm{KC}]$

36. 'Abd al-Rahmmān Țā-Hāâ, Su'âl al-akhlāq [The Question of Ethics] (al-Markaz al-Thaqāfì al'Arabī).

37. [AT employs for 'ethical acts' the term af'all khuluqĩyah, and goes on to speak of al-akhläq generally rendered as 'ethics'. Yet in its original Arabic context akhlāq (singular khuluq) specifically connotes 'character traits' whether innate or acquired; so in his essay akhlāq may denote praiseworthy traits or ethical 'virtues' as well as Ethics. KC] 
second division in itself comprises two sorts of actions: one being immediate acts having a spiritual exterior as when the human prays, his prayer does not initiate a virtuous-trait $[$ khuluq] but bequeaths the virtuous-trait of 'abstention from vile deeds'. The second kind is far-reaching acts as when the man provides material support for his father, this act does not initiate a virtuous-trait nor is the benefit gained by the father by means of such support a virtuous-trait, but the act bequeaths to its doer the virtuous-trait of 'filial piety'.

(b) Ethical-Traits [al-akhlāq] are acquired from religion. The elucidation of this is that ethical-traits revolve around good and evil, and good and evil are two values not proceeding from the factual realm, since the factual only generates the factual, while the value [al-qīmah] is a binding matter other than the factual, ${ }^{38}$ just as neither proceed from independent reason ${ }^{39}$ since independent reason only generates lawful-axioms $[a l-q \bar{a} n \bar{u} n]$. As for value it expresses an ideal, and the ideal is contrary to the axiom because doubt precedes the axiom and may be followed by error, whereas certainty precedes the ideal and only correctness follows it. There remains only that the source-origin of ethical-traits is in religion, at least in their roots, so that reason originates as a branch from ethical-traits [or Ethics] through one of its reasoning mechanisms. Thus some thinkers surmise that all the character-traits root and branch are produced by human intelligence-reason. ${ }^{40}$

(c) Ethical-Traits are of three grades. We stated that every act consists of an expedient-means or performance for realising an intent-objective or a value [maqsid aw qimah]. However, definitive certainty might occur to the advantage of this intent (or value) or it may not occur, just as definitive certainty might obtain to the benefit of this means (or performance) or it may not obtain. Ethical-traits vary in accordance with their differing shares of certainty to the advantage of intents-objectives, and of shares of certainty to the benefit of means. Therefore, (1) the 'corroborated ethical-traits' are those which are of definitive advantage in intent and definitive benefit in means; while (2) the 'directed-focused ethical-traits' are those which are of definitive advantage

38. 'Abd al-Raḥmān Ṭā-Ḥā, Su'āl al-akhlāq, first chapter.

39. 'Independent autonomous reason' (al- 'aql al-mustaqill) is a technical term in the discipline of the 'roots of jurisprudence' occurring in al-Shāțibī in his al-Muwāfaqāt, meaning 'reason independent of revelation' also termed 'pure reason' - as opposed to 'reason fettered by revelation' or 'reason adhering to revealed law', which is of two sorts: 'reason adhering to revealed·law in its higher objectives' and 'reason adhering to revealed-law in its higher-objectives together with its instrumental-means'. I have designated these latter two respectively as 'directed reason' (al-'aql al-musaddad) and 'corroborated reason' (al-'aql al-mu'ayyad).

40. [AT refers here to the widespread view attested in early Islamic utterances that the chief ethical traits are subsumed under the leading virtue or character-trait of al-'aql - construed as 'intelligence-reason' or 'wisdom-understanding'; see e.g. the famous early maxim 'God is not worshipped with anything more surpassing than the intelligence-reason.' $\mathrm{KC}]$ 
in intent and presumptive benefit in means; while (3) the "purely-divested ethical-traits ${ }^{41}$ are those which are of presumptive advantage in intent and presumptive benefit in means. ${ }^{42}$

\section{Critique of the Foundations of Value Pluralism}

(a) Critique of the Principle of Contradiction between Reason and Religion. Now we ignite the criticism of the first principle from which Value Pluralism branches out yielding rational unrestraint, namely 'the principle of conflict between reason and religion'. Secularity is built upon this conflict, so this pluralist doctrine is one of its outcomes. Here we do not wish to oppose secularity, rather we want to contemplate this conflict by means of that which uncovers its leading to the antithesis of its secular goal. The immediate notion for the separation between the rational and the religious are two ideas, both of which are invalid: one is that religion has nothing of reason in it, and the second is that reason has nothing of religion in it. Elucidation of the invalidity of the first idea is that the religious text does not come absolutely free of rational proof, rather it may contain what the non-religious text clearly comprises. Certainly wherever the rational proof is found, there reason is; thus there exists a measure of reason in the religious text to a greater or lesser degree, alongside something else in the purport of the religious text which some persons cut short thereby falling into the error of generalisation - this thing being faith [īmān $]$. Of course, the definition of faith is conviction without a proof from independent reason - or in our terminology 'purely-divested' reason - that is to say, faith is a non-rational resolution! When those persons employ the expression 'religious text' they mean 'faith text' - and the two wordings differ, as you can see.

Elucidation of the invalidity of the second idea - namely, that independent reason or purely-separated reason has nothing of religion in it - is that not everything in the rational proof is demonstrably proven, but we find in it what

41. Here I call attention to the notion of 'pure' (mujarrad) not being employed in the ordinary sense of 'separate from the senses' or 'freed from matter', but rather with the meaning of 'divested of revelation' or 'freed from religion'. Thus the 'purely-divested ethical-traits' are those ethical virtues whose creator has recourse only to independent-autonomous reason (i.e., secular ethics); so they possess no certainty, because the source of certainty is revelation alone.

42. [In this dense passage AT summarises results of previous work in his The Question of Ethics, distinguishing between three degrees of ethical-traits reflecting the benefit productive of definitive certainty (al-yaqīn aw al-qaț), or merely of presumptive opinion (zanniyyah): 1.alakhlāq al-mu'ayyadah, 2. al-akhlāq al-musaddadah, and 3. al-akhlāq al-mujarradah. (Below, AT orders them in reverse for his treatment of the relation between culture and ethics.) This fundamental epistemic distinction between 'certainty' and 'presumptive opinion' is central to the Islamic discipline of rational theology $(\mathrm{kala} m)$, from whence it was taken up in the 'roots of jurisprudence' (ușūl al-fiqh). KC] 
is not rationally demonstrated starting from the premises and ending with the rules of reasoning. Together these form the object of unquestioning consent, and clearly consent is acceptance without proof so it is a variety of faith. Hence there is a share of faith within the rational proof, namely a share of non-rational decisions. Not only this, but the intellect's choice of a method for dealing with the clash of values - in addition to this being an ethical choice - is an obvious faith decision, to the point that one theorist of modern rationalism speaks in this respect about "faith in reason". ${ }^{43}$ The witness to this being that furnishing proof for reason cannot possibly convince one who does not accept the principles and values upon which the rational demonstration is based.

Since it is evident that there is an element of reason in religion and an element of religion in reason, it is necessary to invalidate both methods pursued for dealing with the clash of values: 'unrestricted determination' and 'unrestricted rational-demonstration', due to the appearance of the first method as founded on pure faith, and the appearance of the second method as founded on pure reason.

(b) Critique of the Principle of Contradiction between Politics and Ethics. We turn now to criticism of the second principle from which Value Pluralism branches out engendering political hegemony, namely 'the principle of conflict between politics and ethics'. In accordance with the first Given [mentioned above] every human act is inevitably tinted with an ethical hue, either at the start or through some intermediary. Accordingly the political activity must be included under the ethical activity, except that such inclusion is not a direct incorporation since the political act is grounded principally upon two bases: 'beneficial Interest' and 'sovereign Power' [al-mașlahah wa 'l-șultah]. Interest is either advantageous and needs to be brought about, or harmful and to be repelled. Bringing about the advantageous interest is a good act, and dispelling the harmful interest is a base act [sic!], while goodness and baseness are two ethical values. Power, the other basis, is either distributed so that it tolerates just measures, or is accumulated so that unjust measures preponderate, while justice and iniquity are two ethical values.

If it is true that Politics is a part of Ethics, then along with this it is also true that the method of 'separation' adhered to in confronting the clash between values is to be resisted. There is no better proof of this than the fact that Rawls in his first book A Theory of Justice [published in 1971] in his discussion of the subject of Justice did not distinguish between political theory and ethical theory. He did not undertake to discriminate between the two except after numerous objections were directed at his philosophic doctrine, especially from

43. See Karl Popper, La société ouverte et ses ennemis (Paris: Seuil, 1979), 2: 153-74. 
those who became known as 'Communitarians'. ${ }^{44}$ Thereupon he found in this method (of 'separation') a handy exit to repel these objections, by making Justice dependent on Politics and the Good dependent on Ethics. In this manner Rawls affected this 'separation' to defend his theory, and the evidence for this affectation is his arranging Justice above the Good - which is absolutely not correct - on the basis that Justice is itself Good and what is embraced by its requisite principles of the values of Equality, Freedom, Respect, Tolerance, Moderation, and Cooperation are in turn Goods. Rawls finally wound up compelled to concede the existence of a dainty little ethical theory - a cramped theory - supporting the concept of Justice, in opposition to the substantial ethical theory - the spacious theory - supporting the concept of the Good. ${ }^{45}$ If it be objected that what Rawls intended by Justice is distributive justice dependent on the equitable division of limited resources and not 'fairness' in the sense of 'integrity of conduct', then we respond that in accordance with the first Given it is conceivable to deem this distribution an ethical act since it is of the type which is an immediate means for realising an ethical objective.

(c) Critique of the Principle of Conformity between Culture and Ethics. Finally we come to critique the third principle from which Value Pluralism branches out engendering cultural extremism, namely 'the principle of conformity between culture and ethics'. We assert that this conformity is not proven true in any respect. In accord with the third Given [mentioned above] ethics are on three degrees: the lowest is 'purely-divested ethics' [al-mujarradah, i.e. secular ethics], the midmost is 'directed ethics' [al-musaddadah, focused], and the highest is 'corroborated ethics' [al-mu'ayyadah, buttressed]. In actuality the feasibility of conformity between culture and ethics is specific to the third ethical degree - a degree disavowed by this school-of-thought in accordance with its disavowal of the mode of acting conforming to religious 'innate-nature' [al-'amal wafqa l-fitrah al-dīnīyah], even though this is nothing other than the sum of values with which the human is created. As for the first and second ethical degrees, there is no conformity between either of them and culture. The elucidation of that is as follows:

44. [From the late 1990s a loosely related group of thinkers reacted to J. Rawls' A Theory of Justice with its view of humans as atomistic individuals, by emphasising the need to balance individual rights and interests with those of the entire community, viewing individuals as shaped by the values and beliefs existing in the communal 'public space' formed by debate over issues within civic organisations in society. These 'Communitarians' include Alastair MacIntyre's After Virtue, Michael Sandel's Liberalism and the Limits of Justice, Charles Taylor's Sources of the Self, and Michael Walzer's Spheres of Justice. KC]

45. A. Berten, P. Da Silveira, and H. Pourtois, Libériaux et communautariens (Paris: Presses universitaires de France, 1997), 33-4. 
- People of corroborated ethics have recourse to the religious texts in their possession, pondering them in order to conduct themselves in conformity with them. They do not content themselves with extracting their higherobjectives or values from these texts, as do people of directed ethics; rather they go beyond this to the personal exertion [al-ijtiha $\bar{d}]$ ] of extracting expedient-means out of these texts conveying them to the realisation of these higher-objectives. So upon these objectives and means they build the assembly of their precepts and rules, adhering to a rational method in this paired extraction broader than the methods followed by those below their level, namely people of directed ethics and even more so people of purely-divested ethics. When corroborated ethics are being sought for in the religious text by all the enlivening factors of the human act - both higher-intents and expedient-means - whichever encompasses human actions in as much as no act is excluded, then (the intents and means) become capable of producing the cultural activity itself; thus the cultural activity is not able to be parted from the ethical activity.

- As for people of directed ethics, who are a scarce few among the multitude, in their recourse to religious texts in their possession and contemplation of them despite the variations among themselves, they halt at the limit of extracting some higher-objectives or basic values from these texts out of which they build their precepts and rules, adhering to a broader rational method in such extraction and building than the method followed by people of purely-divested ethics. As for their means in realising these higherintents or ethical values, they content themselves with deriving them from the evidence of their intellects alone as well as from outside these texts. When directed ethics derives its values from a special text, while culture fashions a wide domain comprising both this text and something outside of it, there is erected between these two extremes of Ethics and Culture a disparity resembling the disparity between the part and the whole. Thus it becomes a limited distinction, since the part belongs to the category of the whole although separated from it in extent.

- As for those producing purely-divested ethics by means of their independent reason, who are the vast majority among the multitude, they earnestly strive to achieve this through the guise of a group of general principles by making them scientific laws corresponding to the universality and independence of these principles, ${ }^{46}$ in such a way that these laws have no linkage with culture in itself. Then they undertake the application of

46. A good example of 'purely-divested ethics' is the ethics of the German philosopher Immanuel Kant. 
these laws to this or that culture, just as they apply scientific laws to these or those facts. Whereas purely-divested ethical-traits are equivalent to determined universals, and cultures are equivalent to particular states upon which these ideal universals descend, the disparity between the two extremes - namely Ethics and Cultures - more than anything else resembles the disparity between the universal and the particular, so it becomes a complete distinction since the particular is not of the genus as the universal although classified under it.

In short, the relation between Culture and Ethics varies in accordance with the varying degrees of ethical-traits. Thus the relation is a clear conformity whenever they become a corroborated ethics, and is a limited disparity whenever they become a directed ethics, and is a complete disparity whenever they become a purelydivested ethics.

In the sequence of distinctions between these three modes of relation between Culture and Ethics, when we ponder the relation of the collective with the particular ['alāqat al-mushtarak bi '-l-khāss ], or the relation of the unified side with the manifold side, we find that the collective side is more potent in corroborative-support $\left[a l-t a^{\prime} y \bar{l} d\right]$ with respect to focusing [al-tas $\left.d \bar{\imath} d\right]$, and more potent in focusing with respect to divesting [al-tajríd] - or the reverse that the particular side is more potent in divesting with respect to focusing, and more potent in focusing with respect to corroboration. And we find that the corroborated ethical-traits due to the intensity of their conjunction with the particular culture become the most far-reaching level of ethics shared among people and the most conducive of their unity. The underlying reason for this being that the ethical collective at the level of corroborative-support does not respond to the cultural particularity from without but issues from its interior; and what arrives from without is detached even if it strives for junction, while what issues from within is conjoined even if it strives for detachment.

There remains a difference between our position of maintaining the conjunction between Culture and Corroborated Ethics and between Walzer's position who holds that Ethics is twofold, given that in his view Ethics comprises 'thick' or distinctive ethical-traits imprinted by Culture and 'thin' or collective ethical-traits disclosed in special occasions. There are three aspects of this difference between the two positions:

(a) The ethical-traits Walzer attends to are basically purely-divested ethical-traits, but when we take into consideration that he contemplates certain texts of the Torah and cites examples of the values it contains, it is possible for us to tolerate extending the scope of ethics Walzer explores by adding to them 
the directed ethical-traits, whereas the corroborated ethical-traits remain completely external to his range of receptivity.

(b) To the extended ethical-traits he attends to, Walzer attributes the conjunction between their thick side affected by culture and their thin side free of this effect. Whereas we clarified how conjunction does not occur in these ethical-traits, rather what transpires in them is dissociation. Dissociation is of two sorts: a comprehensive dissociation with regard to purely-divested ethics, and a partial dissociation with regard to directed ethics.

(c) What Walzer unduly claims concerning the conjunction between the two thick and thin sides does not hold true save for corroborated ethical-traits, which are the ethical-traits he does not attend to nor examine attentively although they spring from the character-traits of human innate-nature [akhlāq al-fitrah] as mentioned in religious texts.

\section{Toward a New Value Pluralism}

To sum up: the principles upon which Value Pluralism is grounded and from which ensues the clash between values - namely 'the principle of conflict between reason and religion' and 'the principle of conflict between politics and ethics' and 'the principle of conformity between culture and non-religious ethics' - are principles refuted by contradictions necessitating that we substitute in their place opposing principles. These are: 'the principle of congruity [al-tawāfuq] between reason and religion' and 'the principle of congruity between politics and ethics' and 'the principle of disparity between culture and non-religious ethics'. Thereby we are entitled to ask: Does the validity of these opposing principles compel upholding the view of the absence of plurality in values and establishing the certainty of their unity? And if this is not the case, then what is the nature of the value pluralism which may feasibly be generated from these principles?

The answer is the need to discriminate between the Value Pluralism which arose from recent conditions, specifically ideological and strategic circumstances, and between the tangibly real plurality we notice in the life of individuals and history of societies and observe in all spatial and temporal circumstances. Evidences for that are innumerable, and it suffices us to mention the history of the Islamic intellectual experience. Due to this actuality, cancelling the contemporary doctrine of Value Pluralism certainly does not require invalidating the principle of 'value plurality' [al-ta addud al-qīmì], nor to be more precise excluding the truth of value plurality. Therefore, we need to originate a new conception of a value plurality with no clash in it, and we may name this new pluralism the 'pluralism of coinciding values' opposed to the 'pluralism of clashing values' we are striving to leave behind. It is unavoidable that coinciding pluralism should beware of three defects which penetrated contemporary clashing pluralism: 'the bane of modern rational unrestraint' 
and 'the bane of ideological political hegemony' and 'the bane of strategic cultural extremism'. This wariness involves the following three aspects:

Grounding Reason upon Faith. We mentioned that the bane of rational unrestraint originates from embracing reason and discarding religion, namely giving free rein to reason.$^{47}$ There is no way to dispel this unrestraint except by means of something which precedes reason, and only faith precedes reason. ${ }^{48}$ The evidence is that embracing reason itself requires faith in it, so that some philosophers strove to the utmost in such rational unrestraint by having recourse to this previous faith in reason; and faith in the free scope of reason is like faith in the free scope of religion, since pure rational-demonstration is of no avail for both of them. Whenever reason supports itself on faith it obtains a guide directing it to a method with respect to pluralism wherein reason is not dissipated and does not stumble about lost; whereas on the contrary reason is dissipated and gropes about in the contemporary pluralist school-of-thought until it is as if reason emerges from the enchanted world in order to enter a deranged world [ $\bar{a}$ lam mams $\bar{u} s] .{ }^{49}$ Rather, on the contrary its reliance upon faith makes reason greatly consolidate its mastery and authority.

Grounding Politics upon The Good. We saw above that the bane of political hegemony originates from embracing politics and forsaking ethics, that is to say giving free rein to politics. There is no way to repulse this hegemony except by attaining the certainty that political theory - whatever its dependent-attachment [muta allaquhā] may be: on sovereign-authority or public-interest or justice or rights - cannot possibly be independent of a theory about the Good, since its dependentattachment certainly possesses a specific value, and this specific value ought to be a Good otherwise the utility of this political theory is voided. Rather we ought to see in Politics itself one of the Good-things, of necessity possessing ethical requisites just as any one of its dependent-attachments possesses. Undoubtedly the Good is not a single degree but multiple degrees, and the more that the Good we attribute to Politics is of a higher degree, then the further away will it be from authoritarian hegemony - so what do you think would be the case when this Good is the most sublime [al-khayr al-asmä']?

Grounding Culture upon Human Innate Naturelal-Fitrah. We pointed out that the bane of cultural extremism originates from accepting culture while spurning

47. [The elegance of wording by AT is lost in our translation here, for he employs three synonyms for 'bridle-rein' ( inān, zimām, lijām) enhancing his meaning of loosening restraint or unfettering which we render by "give free rein to...". It will not be lost on readers conversant with Arabic that the verbal root of 'aql 'intelligence' and 'reason' is derived from the noun 'iqāl 'hobblingcord' with which a camel is parked, the notion of 'reason' flowing from 'self-restraint'. Thus, 'rational unrestraint' is incongruent with the normative Islamic understanding of 'fettered reason' and 'faith in reason'. $\mathrm{KC}]$

48. It is not possible that reason be prior, nor final.

49. What is meant by 'deranged' is the thing being impaired or 'touched' by the Jinn - as in the qur'ānic verse (2:275): "whom Satan has overthrown by the touch". 
religious ethics, namely 'giving free rein to culture'. There is no way to ward off this extremism except by attaining the certainty that Culture, however much its conditions fluctuate and its offerings intensify, shelters a relativist offspring [tazalla nitājan nisbīyan]. We mean: an offspring for a designated people within a specific current domain, even though other peoples may willingly or unwillingly adopt it as their own, and even though the culture comes to pervade all nations of the world. For Culture is a manifest acquirement $[k a s b]$ of the human, and the origin of every acquirement is caused by specific conditions, aside from the fact that there is no existence for a universal human denuded of every current garment. Nevertheless we definitively affirm the existence of values and notions shared in common among all mankind, except that the position of Culture in relation to these collective values consists of three situations:

- either culture rests upon these values together with acknowledging their noncultural origin;

- or it rests upon these values without admitting their non-cultural origin, whether intentionally or inadvertently;

- or culture distorts these values [tuharrifuhā] endeavouring to sever its bond with them, substituting in their place cultural values devoid of the endowment of being shared collectively among nations.

\section{Pluralist Implications for Inter-Civilisational Dialogue}

This aggregate of non-cultural collective values is nothing else but that indicated in the [Islamic tradition] by the term al-fitrah, 'Human Innate Nature'. Thus fitrah is the sum of exemplary ideals [jumlat al-qiyam al-muthali $]$ the human derives from the most sublime Good. Therefore, in proportion to the measure of Culture's resting upon this Innate-Nature and being guided by it in the process of generating its particular values, the farther away will Culture be from zealous-bigotry [al-ta așs $u b$ ] over these values and the closer will it be to openness toward other cultures and collaboration with them.

To summarise the preceding: the pluralism being sought is pluralism without unrestrained rationality, and that can only be through conjoining reason with the basis of faith - so no unbridled reason; also it is pluralism without political hegemony, and that can only be through the junction of politics with the basis of the Good - so no politics without a restraint; and finally it is pluralism without cultural extremism, and that can only be through the conjunction of culture with 'innate-nature' - so no culture without a restraining bridle. 